\title{
HOMEOSTATIC MECHANISMS OF DESERT AND NON- DESERT SHEEP AND GOATS UNDER HARSH ENVIRONMINTAL CONDITIONS
}

\author{
A.M. Hassanien, M.A. Shehab-El-Deen and R. E. Khalifa \\ Department of Animal Production, Faculty of Agriculture, Suez Canal University, \\ 41522 Ismailia, Egypt
}

\section{SUMMARY}

This experiment was carried out to compare heat tolerance of the local Sinai sheep and goats with those of Nile delta breeds (Rahmani sheep and Baladi goats). Twenty animals (5 male of each group) were used in this study. The age of sheep and goats ranged between 12 -18 months. The coat of each animal (wool or hair) had been shorn to maintain its lengths constant at about 1.5 - $2 \mathrm{~cm}$ throughout the study period. All the animals were exposed daily to direct solar radiation (DSR) from 12:00 $h$ to 15:00 $h$ for 7 successive days in August. The averages ambient temperature and relative humidity were $31.75^{\circ} \mathrm{C}$ and $46 \%$, respectively during this study. Data on the following parameters were collected: rectal temperature (RT), respiration rate $(\mathrm{RR})$, hemoglobin concentration $(\mathrm{Hb})$, haematocrit value $(\mathrm{Ht})$, thyroid hormones levels $\left(\mathrm{T}_{3}\right.$ and $\left.\mathrm{T}_{4}\right)$ and acid-base balance $\left(\mathrm{pH}\right.$ and $\mathrm{HCO}_{3}$ ) before and after exposure to DSR.

Results indicated that, exposure of animals to DSR increased significantly $(\mathrm{P}<0.05) \mathrm{RT}, \mathrm{RR}$ and $\mathrm{pH}$ and decreased significantly $\mathrm{Hb}, \mathrm{Ht}, \mathrm{T}_{3}, \mathrm{~T}_{4}$ and $\mathrm{HCO}_{3}$ irrespective of breed. With respect to breed differences, changes in $R T, H T, T_{3}$ and $\mathrm{HCO}_{3}$ after exposure to DSR were significantly lower in sheep compared to those in goats. Moreover, location of breed affected the studied traits. Sinai breeds had higher changes in $\mathrm{RT}, \mathrm{RR}, \mathrm{T}_{3}, \mathrm{pH}$ and $\mathrm{HCO}_{3}$ compared to Nile delta breeds irrespective of sheep and goats.

From this experiment, it could be concluded that, Sinai originated breeds of sheep and goats may have more tolerance to heat stress due to direct exposure to solar radiation than Nile delta originated breeds.

Keywords: Sheep, goats, solar radiation, hematology, hormones, acid-base balance

\section{INTRODUCTION}

In Sinai, the majority of the domestic animals populations are sheep and goats which are used for the production of meat, milk and fiber (wool or hair). Sheep and goats in Sinai area are managed and produced under an extensive production system. This leads to be more exposed to the direct harsh natural conditions (high temperature, solar radiation, humidity, heat load...etc.) and varying seasonal nutritional conditions. In Sinai desert, direct solar radiation (DSR), particularly, in summer season causes physiological stress involving unfavorable metabolic disturbance which lead to changes in body temperature and respiration rate, osmosis

Issued by The Egyptian Society of Animal Production 
and pH (Azamel et al., 1984; Shalaby, 1985; El-Ganaieny, 1986 and Khalifa et al., 1987). Respiration system plays an important role in controlling changes in these conditions due to low efficiency of sweat glands and heavy wool coat in sheep and dense hair coat in goats which impair heat dissipation via skin surface. High frequency of respiration rate results in hyperventilation, which is apt to causing depletion of $\mathrm{CO}_{2}$ from the body, consequently inducing alkalosis case (Shafie et al., 1994a and b). Studies on the adaptability of different breeds of sheep and goats to hot climate in Egypt had revealed that native breeds are more tolerat than the other exotic breeds. Therefore, the objective of this research was to compare the homeostatic mechanisms of Sinai native sheep and goats with those of Nile delta breeds Rahmani sheep and Baladi goats under heat stress of direct solar radiation during summer season.

\section{MATERIALS AND METHODS}

\section{Animals and management:}

This work was carried out in the Experimental Farm, Animal Production Department, Faculty of Agriculture, Suez Canal University, Ismailia, Egypt. The study was carried out male Egyptian native sheep (Rahmani and Sinai) (5 rams of each breed) and male Egyptian native goats (Baladi and Sinai) (5 bucks of each breed).. All the animals ( $\mathrm{n}=20)$ were 12 - 18 months old with average body weight of :54.55 for Rahmani sheep, $31.77 \mathrm{~kg}$ for Sinai sheep, $30.46 \mathrm{~kg}$ for Baladi goat and $28.05 \mathrm{~kg}$ Sinai goat. The coat of each animal (wool of rams or hair of bucks) had been shorn to maintain its lengths constant at about $1.5-2 \mathrm{~cm}$ throughout the study period. All the animals exposed to DSR, daily for 3 hours from 12:00 h to 15:00 $\mathrm{h}$ for 7 successive days in August.

The animals were housed in semi-open pen allover the period of experiment and fed rice straw ad. libitum and concentrate ration $(500 \mathrm{~g} / \mathrm{head}$ daily, yellow corn $47 \%$, wheat bran $40 \%$, soybean meal $10 \%$, lime stone $2 \%$, common salt $1 \%$ ) during the summer season.

\section{Studied traits:}

Ambient air temperature (AT) and relative humidity (RH\%) were recorded simultaneously at the times of testing the physiological traits using minidrum hygrothermograph (625 East Bunker Court, Vernon Hills, Illinois 60061-1844 U.S.A.). located about 1.5 meters above the ground. This equipment was from ColeParmer Company with accuracy of $\pm 2{ }^{\circ} \mathrm{C}$ and $\pm 5 \% \mathrm{RH}$

Rectal temperature and respiration rate were determined for each animal just before collection of blood samples. Rectal temperature (RT) was measured by inserting clinical thermometer to the depth of 5-6 cm into the rectum, left for two minutes and read to the nearest $0.2{ }^{\circ} \mathrm{C}$. Respiration rate (RT) was counted by the consistent flank movements per one minute. One complete inward and outward movement of the flank was considered as one cycle. For collecting blood samples the animals were deprived of feed and water about 16 hours before collecting the samples.

Three blood samples were collected from the jugular vein of each animal at each test. The first sample was collected under a thick layer (3-ml) of neutral paraffin oil to avoid contact with air, thus to prevent loss in $\mathrm{CO}_{2}$ from blood. This sample was 
centrifuged and serum was transferred to another tube under liquid paraffin to determine bicarbonate. Serum bicarbonate was determined by the titration method of Van Slyke (1922) as reported by Oser (1965).

The second sample (about $1 \mathrm{ml}$ ) was collected in heparinized tube for determination of haemoglobin concentration and haematocrit value. Haematocrit was determined by microhaematocrit centrifuge at $1500 \mathrm{rpm}$ for 15 minutes. Haemoglobin was determined using spectrophotometer by method based on conversion of haemoglobin into red cyanmethemoglobin under the influence of potassium ferricyanide and potassium cyanide.

The third sample $(5 \mathrm{ml})$ was taken into heparinized centrifuge tube to measure blood $\mathrm{pH}$ and thyroid hormones. Blood $\mathrm{pH}$ was measured by inserting the electrode of $\mathrm{pH}$ meter into the centrifuge tube containing the blood just after collection. Then, the sample was centrifuged (3000 rpm for 15 minutes) to obtain plasma. The plasma was transferred into another tube and stored in deep freezer $\left(-20{ }^{\circ} \mathrm{C}\right)$ for determination of triiodothyronin hormone $\left(T_{3}\right)$ and Thyroxine hormone $\left(T_{4}\right) . T_{3}$ and $\mathrm{T}_{4}$ levels were measured by a direct radioimmuno assay using coat-A-count kits (Diagnostic Products Corporation). The antisera for both hormones were highly specific with an extremely low cross reactivity to other hormones. All these parameters were taken immediately before and after exposure DSR.

\section{Statistical analysis:}

Data were analyzed using the General Linear Model (GLM) procedure of SAS (1998). Means were statistically differentiated using Duncan's Multiple Range test (Duncan, 1955).

\section{RESULTS AND DISCUSSION}

\section{Meteorological Data:}

This study was carried out in summer (August), the applied heat stress was that of DSR for three hours at midday from 12:00 till 15:00 h. Table (1) shows the mean AT and RH coinciding with the biological tests of sheep and goats.

Table 1. Ambient temperature (AT ${ }^{\circ} \mathrm{C}$ ) and relative humidity (RH \%) before and after exposure to direct solar radiation in summer

\begin{tabular}{ccccc}
\hline Item & Breed & Before & After & Overall \\
\hline \multirow{3}{*}{ AT } & Goat & 30 & 34 & $\mathbf{3 2}$ \\
& Sheep & 30 & 33 & $\mathbf{3 1 . 5}$ \\
& Overall & $\mathbf{3 0}$ & $\mathbf{3 3 . 5}$ & $\mathbf{3 1 . 7 5}$ \\
RH & Goat & 50 & 40 & $\mathbf{4 5}$ \\
& Sheep & 50.5 & 44 & $\mathbf{4 7 . 2 5}$ \\
& Overall & $\mathbf{5 0 . 2 5}$ & $\mathbf{4 2}$ & $\mathbf{4 6}$ \\
\hline
\end{tabular}

\section{Thermorespiratory responses:}

Results indicated that DSR caused significant increase in both RT and RR in all breeds and the values are represented in Tables ( 2 and 3). It could be noted that in spite of the increase in RR by 98, 125, 138 and $122 \%$ in Baladi and Sinai bucks and Rahmani and Sinai rams, respectively the RT increased by only $1,1.5,1$ and $1.5 \%$, 
respectively. The rise in $\mathrm{RT}$ and $\mathrm{RR}$ in all cases did not exceed than $0.57^{\circ} \mathrm{C}$ and 97.63 resp./min. The Sinai bucks had higher increase of RT and RR than Baladi bucks. However, in rams the Sinai had higher RT and lower RR than the Rahmani rams as illustrated in Tables (2 and 3). Anyhow in spite of high variation in RR, the RT changed in narrow range indicating that the animals could increase their respiratory frequency to dissipate more heat without an increase in their body temperature. ElSherbiny et al. (1983a) found that increasing AT from 20 to $40^{\circ} \mathrm{C}$ increased RT of goats by $1.5^{\circ} \mathrm{C}$, while RR increased from $28 \mathrm{resp} . / \mathrm{min}$ at $20^{\circ} \mathrm{C}$ to $60 \mathrm{resp} . / \mathrm{min}$. and $120-160 \mathrm{resp} . / \mathrm{min}$. at 35 and $40^{\circ} \mathrm{C}$, respectively. The beneficial case of respiration in those subtropical breeds is in favour of efficient action in checking further increase in body temperature (Ashmawy, 1994). The high increase in respiration rate is a physiological response to exposure to solar radiation to increase respiratory evaporation and to increase heat loss through evaporation of water via respiratory system. Similar trends were observed on goats by Appleman and Delouche (1958), Shalaby and Johnson (1993), Kumar and Singh (1994) and Abd-El-Khalek (1997) and on sheep by Khalifa (1982), Shalaby et al. (1989a) and Ashmawy (1994).

Table 2. Mean \pm SE of rectal temperature $\left({ }^{\circ} \mathrm{C}\right)$ of goats (Baladi and Sinai) and sheep (Rahmani and Sinai) before and after exposure to direct solar radiation

\begin{tabular}{|c|c|c|c|c|c|}
\hline \multicolumn{2}{|c|}{ Breed } & Before exposure & After exposure & Change & Change $\%$ \\
\hline \multirow{3}{*}{ Goat } & Baladi & $39.87 \pm 0.05$ & $40.29 \pm 0.06$ & 0.42 & 1 \\
\hline & Sinai & $39.53 \pm 0.03$ & $40.10 \pm 0.05$ & 0.57 & 1.5 \\
\hline & Overall & $39.70 \pm 0.04^{a}$ & $40.20 \pm 0.04^{b}$ & 0.50 & 1.25 \\
\hline \multirow{3}{*}{ Sheep } & Rahmani & $39.67 \pm 0.04$ & $40.11 \pm 0.07$ & 0.44 & 1 \\
\hline & Sinai & $39.34 \pm 0.04$ & $39.90 \pm 0.10$ & 0.56 & 1.5 \\
\hline & Overall & $39.54 \pm 0.04^{a}$ & $40.02 \pm 0.06^{b}$ & 0.48 & 1.25 \\
\hline
\end{tabular}

${ }^{\mathrm{a}, \mathrm{b}}$ values that have different superscript in the same row are significantly different $(\mathrm{P}<0.01)$

Table 3. Mean $\pm \mathrm{SE}$ of respiration rate (resp./min.) of goats (Baladi and Sinai) and sheep (Rahmani and Sinai) before and after exposure to direct solar radiation

\begin{tabular}{|c|c|c|c|c|c|}
\hline \multicolumn{2}{|c|}{ Breed } & Before exposure & After exposure & Change & Change $\%$ \\
\hline \multirow{3}{*}{ Goat } & Baladi & $50.11 \pm 3.17$ & $99.46 \pm 5.66$ & 49.35 & 98 \\
\hline & Sinai & $59.71 \pm 4.12$ & $134.40 \pm 5.91$ & 74.69 & 125 \\
\hline & Overall & $54.91 \pm 2.64^{\mathrm{a}}$ & $116.93 \pm 4.57^{b}$ & 62.02 & 113 \\
\hline \multirow{3}{*}{ Sheep } & Rahmani & $70.57 \pm 5.04$ & $168.20 \pm 4.36$ & 97.63 & 138 \\
\hline & Sinai & $65.38 \pm 5.11$ & $145.52 \pm 7.15$ & 79.84 & 122 \\
\hline & Overall & $67.97 \pm 3.7^{\mathrm{a}}$ & $158.75 \pm 4.14^{b}$ & 90.78 & 133 \\
\hline
\end{tabular}

${ }^{\mathrm{a}, \mathrm{b}}$ values that have different superscript in the same row are significantly different $(\mathrm{P}<0.01)$.

\section{Haematological traits:}

Results indicated that heat stress caused a significant variation in $\mathrm{Hb}$ and $\mathrm{Ht}$ in both sheep and goats. Tables (4 and 5) reveal that exposure to direct solar radiation decreased significantly $\mathrm{Hb}$ and $\mathrm{Ht}$, this reduction may be due to the destruction of erythrocytes at high ambient temperature (Olbrich et al. 1972). Reece (1991) reported that the reduction might be due to reducing the circulating RBCs in peripheral circulation to check metabolism and metabolic heat production, most probably by 
increasing storage in spleen. The spleen is an important resevoair of blood, especially of RBCs, contraction of the spleen occurs when more RBCs are needed in peripheral circulation. The same results were found also by Appleman and Delouche (1958), and Ashmawy (1994).

On the other hand Khalifa et al. (1987) studied the response of Ossimi and Merino sheep to severe heat stress of direct solar radiation in summer. They found that the plasma volume was decreased by $15.9 \%$ in Ossimi and $22.9 \%$ in Merino, denoting that the decrease in both $\mathrm{Hb}$ and $\mathrm{Ht}$ not due to haemodilution. From another point of view, the reduction in $\mathrm{Hb}$ and $\mathrm{Ht}$ may be due to reduce blood viscosity. The reduction of blood viscosity facilitates the mobilization of the blood towards the animal surface and skin capillaries, which increase the efficiency of heat dissipation through the physical law of radiation, convection and conduction (Shafie and Badreldin, 1962). However the low value of $\mathrm{Hb}$ and $\mathrm{Ht}$ is an adaptive character to diminish the metabolic heat production.

Table 4. Mean \pm SE of haemoglobin concentration (g/dl blood) of goats (Baladi and Sinai) and sheep (Rahmani and Sinai) before and after exposure to direct solar radiation

\begin{tabular}{|c|c|c|c|c|c|}
\hline \multicolumn{2}{|c|}{ Breed } & Before exposure & After exposure & Change & Change $\%$ \\
\hline \multirow{3}{*}{ Goat } & Baladi & $8.54 \pm 0.11$ & $7.77 \pm 0.09$ & -0.77 & -9 \\
\hline & Sinai & $8.90 \pm 0.07$ & $8.06 \pm 0.07$ & -0.84 & -9 \\
\hline & Overall & $8.72 \pm 0.07^{\mathrm{a}}$ & $7.91 \pm 0.06^{b}$ & -0.81 & -9 \\
\hline \multirow{3}{*}{ Sheep } & Rahmani & $10.83 \pm 0.10$ & $10.15 \pm 0.09$ & -0.68 & -6 \\
\hline & Sinai & $9.28 \pm 0.25$ & $8.42 \pm 0.25$ & -0.86 & -9 \\
\hline & Overall & $10.17 \pm 0.16^{a}$ & $9.41 \pm 0.16^{b}$ & -0.76 & -7.5 \\
\hline
\end{tabular}

$\mathrm{a}, \mathrm{b}$ values that have different superscript in the same row are significantly different $(\mathrm{P}<0.01)$

Table 5. Mean \pm SE of haematocrit value (\%) of goats (Baladi and Sinai) and sheep (Rahmani and Sinai) before and after exposure to direct solar radiation

\begin{tabular}{cccccc}
\hline \multicolumn{2}{c}{ Breed } & Before exposure & After exposure & Change & Change \% \\
\hline \multirow{4}{*}{ Goat } & Baladi & $28.81 \pm 0.41$ & $27.14 \pm 0.44$ & -1.67 & -6 \\
& Sinai & $29.75 \pm 0.27$ & $27.82 \pm 0.21$ & -1.93 & -6.5 \\
& Overall & $\mathbf{2 9 . 1 9} \pm \mathbf{0 . 2 5}^{\mathbf{a}}$ & $\mathbf{2 7 . 4 8} \pm \mathbf{0 . 2 4}^{\mathbf{b}}$ & $\mathbf{- 1 . 7 1}$ & $\mathbf{- 6}$ \\
\multirow{5}{*}{ Sheep } & Rahmani & $34.37 \pm 0.25$ & $32.13 \pm 0.25$ & -2.24 & -6.5 \\
& Sinai & $28.75 \pm 0.61$ & $27.23 \pm 0.67$ & -1.52 & -5.5 \\
& Overall & ${\mathbf{3 2 . 0 3} \pm \mathbf{0 . 4 6}^{\mathbf{a}}}^{\mathbf{a}}$ & $\mathbf{3 0 . 0 5}^{\mathbf{0 . 4 5}}$ & $\mathbf{- 1 . 9 8}$ & $\mathbf{- 6}$ \\
\hline
\end{tabular}

$\mathrm{a}, \mathrm{b}$ values that have different superscript in the same row are significantly different $(\mathrm{P}<0.01)$

\section{Thyroid hormones:}

Data in Table (6) revealed that exposure to direct solar radiation did not affect significantly thyroid hormones $\mathrm{T}_{3}$ or $\mathrm{T}_{4}$. However the concentration of both hormones decreased in both breeds of sheep and goats after exposure to direct solar radiation as shown in Tables 6 and 7. These decreases might be due to reducing metabolic heat production as a response to heat load where $T_{3}$ and $T_{4}$ are recognized as powerful metabolic agents (Khalil, 1980; Khalifa, 1982 and Abd-El-Bary, 1982). These results are admitted those by El-Sherbiny et al. (1983b) on Barki sheep and Shalaby and Shehata (1995) on Finn sheep. 
Table 6 Mean \pm SE of $\left(\mathrm{T}_{3}\right)$ Triiodothyronin hormone (ng/dl) of goats (Baladi and Sinai) and sheep (Rahmani and Sinai) before and after exposure to direct solar radiation

\begin{tabular}{|c|c|c|c|c|c|}
\hline \multicolumn{2}{|c|}{ Breed } & Before exposure & After exposure & Change & Change $\%$ \\
\hline \multirow{3}{*}{ Goat } & Baladi & $87.21 \pm 5.61$ & $75.08 \pm 7.79$ & -12.13 & -13.9 \\
\hline & Sinai & $80.51 \pm 7.96$ & $67.91 \pm 5.70$ & -12.60 & -15.7 \\
\hline & Overall & $83.86 \pm 6.49^{a}$ & $71.50 \pm 6.53^{a}$ & -12.36 & -14.7 \\
\hline \multirow{3}{*}{ Sheep } & Rahmani & $91.83 \pm 10.28$ & $74.19 \pm 8.18$ & -17.64 & -19 \\
\hline & Sinai & $85.60 \pm 10.11$ & $63.27 \pm 2.46$ & -22.33 & -26 \\
\hline & Overall & $88.72 \pm 7.18^{a}$ & $68.73 \pm 4.13^{a}$ & -19.99 & -22.5 \\
\hline
\end{tabular}

Values that have the same superscript in the same row are not significantly different

Table 7. Mean \pm SE of $\left(\mathrm{T}_{4}\right)$ thyroxine hormone (ug/dl) of goats (Baladi and Sinai) and sheep (Rahmani and Sinai) before and after exposure to direct solar radiation

\begin{tabular}{|c|c|c|c|c|c|}
\hline \multicolumn{2}{|c|}{ Breed } & Before exposure & After exposure & Change & Change \% \\
\hline \multirow{3}{*}{ Goat } & Baladi & $5.13 \pm 0.21$ & $4.63 \pm 0.20$ & -0.50 & -9.75 \\
\hline & Sinai & $5.38 \pm 0.25$ & $5.24 \pm 0.31$ & -0.14 & -2.60 \\
\hline & Overall & $5.26 \pm 0.20^{\mathrm{a}}$ & $4.94 \pm 0.23^{\mathrm{a}}$ & -0.32 & -6.10 \\
\hline \multirow{3}{*}{ Sheep } & Rahmani & $5.68 \pm 0.23$ & $5.36 \pm 0.43$ & -0.32 & -5.63 \\
\hline & Sinai & $4.58 \pm 0.37$ & $4.26 \pm 0.25$ & -0.32 & -7 \\
\hline & Overall & $5.13 \pm 0.21^{\mathrm{a}}$ & $4.81 \pm 0.25^{a}$ & -0.32 & -6.24 \\
\hline
\end{tabular}

Values that have the same superscript in the same row are not significantly different

Results revealed that the decrease in plasma level of $\mathrm{T}_{3}$ in Sinai bucks was slightly greater than that in Baladi bucks (12.60 vs. $12.13 \mathrm{ng} / 100 \mathrm{ml}$ ). The same trend was found in sheep where the Sinai rams showed greater decrease than Rahmani rams (22.33 vs. $17.64 \mathrm{ng} / 100 \mathrm{ml})$.

In accordance with plasma $\mathrm{T}_{4}$ levels the Baladi bucks showed greater decrease than Sinai bucks $(0.50$ vs. $0.14 \mathrm{ug} / 100 \mathrm{ml})$ but in ram the two breeds showed the same value of decreasing plasma $\mathrm{T}_{4}$ levels $0.32 \mathrm{ug} / 100 \mathrm{ml}$ of both Rahmani and Sinai rams. Heat as a systemic stress factor, evokes a generalized adaptive pattern in which the whole body, and particularly, the endocrine system participate. (Selye 1950). The significance of decrease in thyroid activity in the present study was to reduce metabolic rate then metabolic heat production to face the heat load by high temperature in external environment.

\section{Acid-base balance:}

Exposure to DSR showed insignificant effect on blood $\mathrm{pH}$ or serum $\mathrm{HCO}_{3}$ concentration except in rams (Table 8). The overall serum $\mathrm{HCO}_{3}$ in rams differed significantly due to heat stress. Tables ( 8 and 9) show the value of blood $\mathrm{pH}$ and serum $\mathrm{HCO}_{3}$ concentration before and after exposure to DSR. It could be noted that the serum $\mathrm{HCO}_{3}$ concentration decreased slightly in bucks $(0.52$ and $0.94 \mathrm{~m} \mathrm{~mol} / \mathrm{l}$ for Baladi and Sinai bucks, respectively), while in rams that decrease was ( 2.25 and 2.68 $\mathrm{m} \mathrm{mol} / \mathrm{l}$ for Rahmani and Sinai rams, respectively). In spite of these decreases in 
serum $\mathrm{HCO}_{3}$ concentrations the blood $\mathrm{pH}$ changed in narrow ranges, between 0.1 and $0.3 \%$. The blood $\mathrm{pH}$ did not change in Baladi bucks or Rahmani rams and it remained stable at 7.21 for Baladi bucks and 7.19 for Rahmani rams. In case of Sinai bucks and rams the blood $\mathrm{pH}$ increased by 0.02 . These phenomena may reflect the adaptability of these subtropical breeds to hot condition. Schneider (1988) found that $\mathrm{HCO}_{3}$ of Holstein cows decreased to $21.24 \mathrm{~m} \mathrm{~mol} / \mathrm{L}$ after heat stress compared to $23.45 \mathrm{~m}$ $\mathrm{mol} / \mathrm{L}$ in thermo-neutral case. On the other hand, Ashmawy (1994) found slight increase in serum $\mathrm{HCO}_{3}$ concentration after heat stress in Ossimi and Merino sheep.

Table 8. Mean \pm SE of blood pH of goats (Baladi and Sinai) and sheep (Rahmani and Sinai) before and after exposure to direct solar radiation

\begin{tabular}{|c|c|c|c|c|c|}
\hline \multicolumn{2}{|c|}{ Breed } & Before exposure & After exposure & Change & Change $\%$ \\
\hline \multirow{3}{*}{ Goat } & Baladi & $7.21 \pm 0.01$ & $7.21 \pm 0.02$ & 0.00 & --- \\
\hline & Sinai & $7.21 \pm 0.02$ & $7.23 \pm 0.02$ & 0.02 & 0.3 \\
\hline & Overall & $7.21 \pm 0.01^{\mathrm{a}}$ & $7.22 \pm 0.01^{\mathrm{a}}$ & 0.01 & 0.1 \\
\hline \multirow{3}{*}{ Sheep } & Rahmani & $7.19 \pm 0.02$ & $7.19 \pm 0.02$ & 0.00 & --- \\
\hline & Sinai & $7.23 \pm 0.02$ & $7.25 \pm 0.03$ & 0.02 & 0.3 \\
\hline & Overall & $7.21 \pm 0.01^{\mathrm{a}}$ & $7.22 \pm 0.02^{\mathrm{a}}$ & 0.01 & 0.1 \\
\hline
\end{tabular}

Table 9. Mean $\pm \mathrm{SE}$ of serum bicarbonate concentration ( $\mathrm{m} \mathrm{mol} / \mathrm{L}$ ) of goats (Baladi and Sinai) and sheep (Rahmani and Sinai) before and after exposure to direct solar radiation

\begin{tabular}{|c|c|c|c|c|c|}
\hline \multicolumn{2}{|c|}{ Breed } & Before exposure & After exposure & Change & Change \% \\
\hline \multirow{3}{*}{ Goat } & Baladi & $22.43 \pm 1.12$ & $21.91 \pm 0.89$ & -0.52 & -2.3 \\
\hline & Sinai & $23.83 \pm 1.17$ & $22.89 \pm 1.17$ & -0.94 & -4.0 \\
\hline & Overall & $23.13 \pm 0.80^{a}$ & $22.40 \pm 0.73^{a}$ & -0.73 & -3.2 \\
\hline \multirow{3}{*}{ Sheep } & Rahmani & $23.11 \pm 1.00$ & $20.86 \pm 0.75$ & -2.25 & -9.7 \\
\hline & Sinai & $23.08 \pm 1.05$ & $20.40 \pm 0.95$ & -2.68 & -11.6 \\
\hline & Overall & $23.10 \pm 0.72^{a}$ & $20.67 \pm 0.58^{b}$ & -2.43 & -10.5 \\
\hline
\end{tabular}

${ }^{\mathrm{a}, \mathrm{b}}$ values that have different superscript in the same row are significantly different $(\mathrm{P}<0.01)$.

In the present study the acid-base balance was not interrupted in both Baladi bucks and Rahmani rams. In spite of increased respiration rate or the decrease of serum $\mathrm{HCO}_{3}$ concentration from 22.43 to $21.91 \mathrm{~m} \mathrm{~mol} / \mathrm{L}$ and from 23.11 to $20.86 \mathrm{~m}$ mol / L, respectively, there was stability of blood $\mathrm{pH}$. On the other hand in Sinai breeds, the acid-base balance was slightly interrupted because the change in $\mathrm{HCO}_{3}$ concentration was higher than that of Baladi bucks and Rahmani rams.

Ashmawy (1994) reported that increasing respiration rate if accompanied with non or slight drop in tidal volume would cause hyperventilation which leads to the trouble of increased output of $\mathrm{CO}_{2}$ in expired air. This case is characterized by drop in pressure of carbon dioxide $\left(\mathrm{PCO}_{2}\right)$ in blood with depletion of carbonic acid $\left(\mathrm{H}_{2} \mathrm{CO}_{3}\right)$ the fraction of the major buffer system $\mathrm{HCO}_{3} / \mathrm{H}_{2} \mathrm{CO}_{3}$ accordingly alkalosis case (rise of $\mathrm{pH}$ value) occurs.

From this experiment, it could be concluded that, Sinai originated breeds of sheep and goats may have more tolerance to heat stress due to direct exposure to solar radiation than Nile delta originated breeds. 


\section{REFERENCES}

Abd-El-Bary, H.T.M., 1982. Energetic cost of sheep under Egyptian conditions. Ph.D. Thesis, Fac. Agric., Al-Azhar Univ., Cairo, Egypt.

Abd-El-Khalek, T.M.M., 1997. Adaptability of goats under Egyptian environmental conditions. M.Sc. Thesis, Fac. Agric., Al-Azhar Univ., Cairo, Egypt.

Appleman, R.D. and J.C. Delouche, 1958. Behavioural, Physiological and biochemical responses of goats to temperature, 0 to $40{ }^{\circ}$ C. J. Anim Sci., 17: 326335.

Ashmawy Naema, A., 1994. Adaptation of sheep to hot-arid conditions. Ph.D. Thesis, Fac. Agric., Cairo Univ., Cairo, Egypt.

Azamel, A.A., 1984. A study on some factors affecting heat tolerance and productivity in sheep. Ph. D. Thesis, Fac. Agric., Ain Shams Univ., Cairo, Egypt.

Duncan, D, 1955: Multiple range and multiple F- test. Biometrics, 11, 1- 42.

El-Ganaieny, M.M., 1986. Some physiological studies on sheep under desert conditions. Ph. D. Thesis, Fac Agric., Ain Shams Univ., Cairo, Egypt.

El-Sherbiny, A.A., H.A. El-Oksh, M.K. Yousef, M.H. Salem, and M.H. Khalil, 1983a. Exposure to solar radiation in relation to wool length and plasma calorigenic hormonal picture in desert sheep. Al-Azhar Agricultural Research Bulletin, No. 74

El-Sherbiny, A.A., M.K. Yousef, M.H. Salem, H.H. Khalifa, H.T. Abd-El-Bary and M.H. Khalil, 1983b. Thermo-regulatory responses of desert and non-desert goat breed. Al-Azhar Agric. Res. Bulletin, Fac Agric., Al-Azhar Univ., 89: 1-10.

Khalifa, H.H., 1982. Wool coat and thermoregulation in sheep under Egyptian conditions. Ph.D. Thesis, Fac. Agric., Al-Azhar Univ., Cairo, Egypt.

Khalifa, H.H., A.A. Barghout and A.H. Barkawy, 1987. Effect of exposure to solar radiation accompanied with thirst on some physiological parameters in Ossimi, Merino and their crosses. $12^{\text {th }}$ International Cong for Statistics and Computer Science., March, 1987, Ain Shams Univ., Cairo, Egypt. pp: 95-112

Khalil, M.H., 1980. Studies on the wool coat of sheep and its relation to their adaptability to the Egyptian environment. Ph.D. Thesis, Fac. Agric., Al-Azhar Univ., Cairo, Egypt.

Kumar, P. and K. Singh, 1994. Effect of shearing on thermo-adaptability in goats of arid and semi-arid zone of India. Indian J. Anim Sci., 64: 290-294.

Olbrich, S.E., F.A. Martz, M.E. Tumbeson, H.D. Johnson and E.S. Hilderbrand, 1972. Effects of constant environmental temperature of $10^{\circ} \mathrm{C}$ and $31^{\circ} \mathrm{C}$ on serum biochemical and haematological measurements of heat-tolerant and cold-tolerant cattle. Comp. Biochem. Physiol., 41 (A): 255-266.

Oser, B.L., 1965. Hawk's Physiological Chemistry, $14^{\text {th }}$ Ed. Tata Mc Graw Hill Publishing Co. Ltd. Bombay, New Delhi, India.

Reece, W.O., 1991. Body heat and temperature regulation. Chapter 10, In: Physiology of Domestic Animals. Lea \& Febiger, Philadelphia, USA.

Schneider, P.L., D.K. Beede and C.J. Wilcox, 1988. Nycterohemoral patterns of acidbase status, mineral concentrations and digestive function of lactating cows in natural or chamber heat stress environments. J. Anim. Sci. (66): 112-125.

Selye, H., 1950. The physiology and pathology of exposure to stress. ACTA, Inc. Med. Rub., Montreal. 
Shafie, M.M. and A.L. Badreldin, 1962. The role of blood in regulation body heat in bovines. Egyptian J. Anim. Prod., 2: 61-76.

Shafie, M.M., A.L. Badreldin, N.A. Ashmawy andA.M. Hassanien, 1994a. Plasma bicarbonate in acid-base balance for sheep adaptation to hot condition. Egyptian J. Anim. Prod., Supplement Issue, Nov. (31): 311-321.

Shafie, M.M., A.M. Hassanien and F.M. Abdelghany, 1994b. Thermo-respiratory responses of native and exotic sheep breeds to subtropical hot summer in Egypt. Egyptian J. Anim. Prod., Supplement Issue, Nov. (31): 323-332.

Shalaby, T. and E.I. Shehata, 1995. Effect of dietary energy level and heat stress on the physiological responses of Finn crossbred ewes. Proceeding of $5^{\text {th }}$ Scientific Conference of Animal Nutrition, 1: 87-93. Suez Canal University, Ismailia, Egypt

Shalaby, T.H., 1985. Performance and adaptation of local sheep to varied environmental and managerial conditions. Ph. D. Thesis, Faculty of Agriculture, Cairo University, Egypt.

Shalaby, T.H. and H.D. Johnson, 1993. Heat losses through skin vaporization in goats and cow exposed to cyclic hot environment conditions. Egyptian Anim. Conf. Physiol. Anim. Reprod., El-Fayoum, Egypt.

Shalaby, T.H., M.B. Aboul-Ela and A.M. Aboul-Naga, 1989a. Physiological responses of Barki desert goats, Damascus, Zaraiby and their crosses to heat stress under the semi arid conditions of the Western Desert of Egypt. Third Egyptian-British Conference on Animal, Fish and Poultry Production, Zagazig, Egypt.

Van Slyke, D. D., 1922. J. Bid. Chem., 62: 526. 
ميكانيكية الثبات الذاتى فى والأغنام والماعز الصحراوية والغير صحراوية تحت الظروف

أحمد محد حسنبن، محمد أحمد شهاب اللبين، رضا امام خليفة

قسم الاتتاج الحيواني، كلية الزراعة، جامعة قناة السويس، الاسماعيلية، مصر

تهدف هذه التجربة الى مقارنة التحمل الحراري للأغنام و المـاعز السيناوية مع سلالات الأغنام و المـاعز

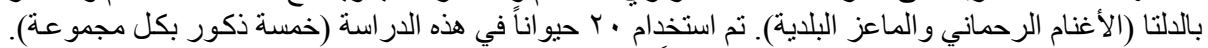

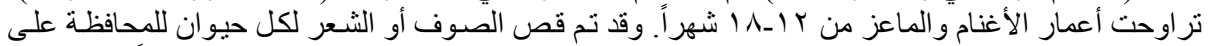

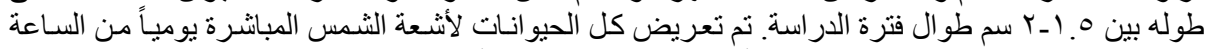

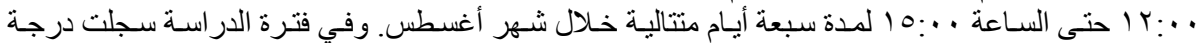

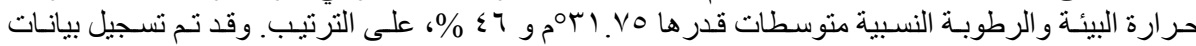

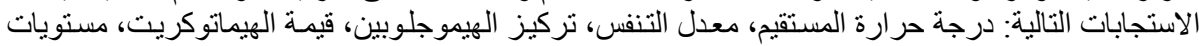

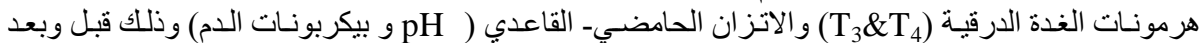

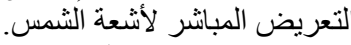

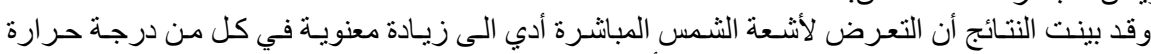

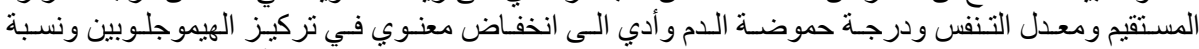

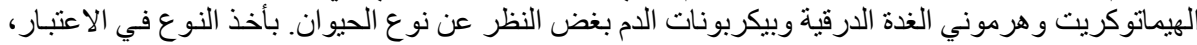

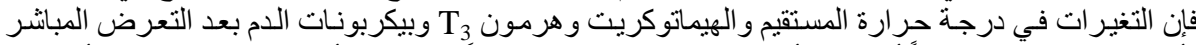

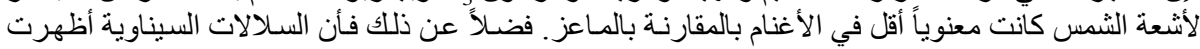

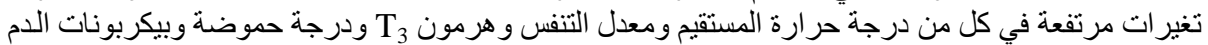

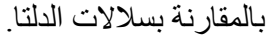

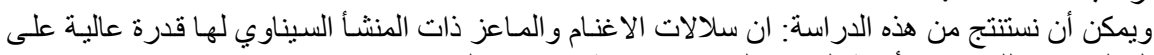

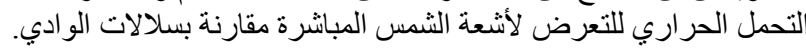

